\title{
Simon Peter's Names in Jewish Sources
}

\author{
MARKus BockMUehl \\ Faculty of Divinity, \\ University of Cambridge
}

imon, Bar Yonah, Peter, Cephas: what, if anything, might St Peter's names $N$ have meant to Palestinian Jews in late antiquity? On a casual approach, the pickings appear very slim indeed. ${ }^{1}$ A second look, however, suggests there may still be some interesting mileage in tracing the significance of those names during the late Second Temple and early rabbinic periods.

The Talmud, to be sure, does not hold out much hope to anyone looking for knowledge of Simon Peter. While it is widely agreed to hint at Jesus and Jewish Christianity on a number of occasions, there is really only one passage that explicitly discusses the immediate disciples of Jesus. ${ }^{2}$ This is the famous censored baraita in $b$. Sanhedrin 43a, missing from standard early printed editions but widely accepted as part of the definitive text: 'Our Rabbis taught: Yeshu had five disciples, Mattai, Nakai, Nezer, Buni and Todah.' The text continues by offering an extended midrashic word play on why all five deserve to be executed .... ${ }^{3}$ We cannot be certain that this tradition of five disciples is of Tannaitic origin, or indeed whether this number derives from a desire either to legitimate or to undermine Jesus. It appears to be stylised in keeping with a similar traditional number of five disciples for both Yohanan ben Zakkai and

\footnotetext{
${ }^{1}$ Earlier versions of this paper were presented at the Durham meeting of the Society for New Testament Studies (2002) and to the senior New Testament Seminar at the University of Oxford (2003). I wish to thank the respective chairmen for their invitation, the seminar participants for their constructive suggestions for improvement, and David Stewart of the library at Princeton Theological Seminary for his generous assistance in sourcing one of the articles cited. Part of this research was supported by a British Academy Research Readership, for which I also wish to express my gratitude.

2 Among the unlikely but theoretically arguable exceptions are Jacob of Kfar Sakhnin in t. Hul. 2.24 (ed. Zuckermandel p. 503); b. 'Abod. Zar. 17a, 27b; Qoh. Rab. 1.24; Miriam 'the hairdresser' (or: of Magdala) and Ben Stada/Ben Pandera in the uncensored section of $b$. $\breve{S} a b$. $104 \mathrm{~b}$, etc.

3 'When Mattai was brought [before the court] he said to them [the judges], Shall Mattai be executed? Is it not written, "Mattai [when] shall I come and appear before God?" (Ps. 42:3). Thereupon they retorted: Yes, Mattai shall be executed, since it is written, "Mattai [when] shall [he] die and his name perish" (Ps. 41:6). When Nakai was brought in he said to them: Shall Nakai be executed? It is not written, "Naki [the innocent] and the righteous slay thou not" (Exod. 23:7)? Yes, was the answer, Nakai shall be executed, since it is written, "In secret places does Naki [the innocent] slay" (Ps. 10:8). When Netzer was brought in, he said: Shall Netzer be executed? Is it not written, And "Netzer [a twig] shall grow forth out of his roots" (Isa. 11:1). Yes, they said, Netzer shall be executed, since it is written, "But thou art cast forth away from the grave like Netzer [an abhorred offshoot]" (Isa. 14:19). When Buni was brought in, he said: Shall Buni be executed? Is it not written, "Beni [my son], my first born" (Exod. 4:22). Yes, they said, Buni shall be executed, since it is written, "Behold I will slay Bine-ka [thy son] thy first-born" (Exod. 4:23). And when Todah was brought in, he said to them: Shall Todah be executed? Is it not written, "A psalm for Todah [thanksgiving]" (Ps. 100:1)? Yes, they answered, Todah shall be executed, since it is written, "Whoso offereth the sacrifice of Todah [thanksgiving] honoreth me" (Ps. 50:23).' The translation follows Jacob Neusner. See e.g. Maier 1978 for a fuller discussion of this passage.
} 
Aqiba; but in any case the avoidance of the New Testament's emphasis on the symbolic circle of Twelve seems likely to be deliberate. The actual names of the five cannot be correlated with any degree of confidence to the New Testament names, although Mattai could be Matthew, Naqai Nicodemus ${ }^{4}$ and Todah Thaddaeus. ${ }^{5}$ Their supposed court hearing on capital charges, along with the appended midrashic arguments for their guilt, is in any case almost certainly a literary artifice of Amoraic origin. However one reads this text, it seems fair to conclude that it reveals nothing of clear pertinence to our question about Simon Peter.

A handful of other Talmudic passages do mention Galilean followers of Jesus by name, most notably the halakhist and healer Jacob of Kfar Sakhnin and the miracle-worker Jacob of Kfar Sema; ${ }^{6}$ but even prima facie none of them seems remotely linked to Peter. A few years ago Joshua Schwartz attempted to link the story of Peter's healing of Aeneas in Lydda (Acts 9:32-35) with the rabbinic tradition of Ben Stada's execution in Lydda as a mesit. But once again the supposed parallels, although intriguing, remain tenuous and unspecific at best, and seem in the end insufficiently cogent to demonstrate a specific historical link. ${ }^{7}$ The rabbis were aware of Jewish Christians in Capernaum $^{8}$ and especially Caesarea, ${ }^{9}$ among other places, but never explicitly in relation to Peter. One Aramaic incantation bowl does invoke Peter along with Jesus and other powers, but this has no parallel in normative rabbinic literature and is in any case difficult to identify with confidence as either Jewish or Christian. ${ }^{10}$

Rabbinic Judaism, then, evidently did not keep alive any independent memory of the 'historical Peter'. Our aim here must be more modest: it is merely to ask what associations the names of Simon Peter would have evoked during the late Second Temple and early rabbinic periods.

Simon, Bar Yonah, Peter, Cephas: the New Testament's four different names for the apostle have long given rise to numerous scholarly theories and explanations. Most commentators regard only 'Peter' and 'Cephas' to be of any great interest or consequence, and their linguistic and cultural setting is

${ }^{4}$ Cf. Bauckham 1996.

5 Thus e.g. Jastrow s.v.; if the otherwise obscure Thaddaeus is the correct reading, the occurrence of his name might shed interesting light on the Palestinian or Syrian Sitz im Leben of this tradition, given Eusebius' association of Thaddaeus with Edessa (Eccl. Hist. 1.12.3). But note Krauss 1902:172n, who identifies Todah as Paul in Codex Huldreich of the Toledot Yeshu.

${ }^{6}$ E.g. b. 'Abod. Zar. 17a, 27b; t. Hul. 2.22-23; y. Abod. Zar. 2, 44d. See also the supposed reference to Mary Magdalene as the mother of Ben Stada (אמו מרים מגדלא) in the uncensored text at $b$. Sanh. 67a and b. Šab. 104b; cf. also b. Hag. 4b.

7 Schwartz 1995; the reference is to $t$. Sanh. 10.11; b. Sanh. 67a; y. Sanh. 7, 25c-d. The assertion on p. 413n.71 of Stada as a pun on Peter's name (כיפא, סטא) seems symptomatic of the nature of the argument.

8 E.g. Qoh. Rab. 1.8; 7.26.

9 The third-century Abahu was closely involved with Christians at Caesarea. He commented, for example, that Palestinian rabbis find themselves compelled to know Scripture better than their Babylonian counterparts, because Christians keep asking them about it. See the discussion in Bacher 1892-99:2.96-97; cf. b. Pesah. 56a; y. Naz. 9.1, 57c on the Christian woman who comes to Abahu asking to be released from a Nazirite vow.

${ }^{10}$ Cf. Isbell 1975, no. 52.3 (פתרוס). 
widely treated as self-evident. Here, by contrast, I wish to contend that ancient Jewish sources, some recently published but most long since ignored by commentators, shed additional light on the resonances of all four names. We will treat each name in turn.

\section{Simon: A Name of the Hasmonean Revival}

We begin with what most readers take for granted as trivial: the name Simon or Simeon, representing Hebrew שמעון. This is of course attested in all four gospels, although elsewhere it is mentioned only in Acts $(10: 5,18,32 ; 11: 13$; $\left.15: 14^{11}\right)$ and 2 Peter $(1: 1$, perhaps as a deliberate allusion to the patriarch in the testamentary genre).

\section{First-Century Popularity}

There is no doubt that Simon had by the end of the Second Temple period become a very popular name. Josephus's own grandfather was called Simon (Life 1 ), and he refers to a total of 29 individuals by that name. ${ }^{12}$ They include most famously Simeon the Just, the son of Onias the High Priest (Ant. 12.2.5 $\S 43,12.4 .10 \S 224),{ }^{13}$ Simon the son of Hasmoneus the priest (Ant. 12.6.1 §238) as well as the latter's great-grandson Simon Maccabeus (Ant. 12.8.2 §332 and passim); Herod's father-in-law the High Priest Simon son of Boethus (Ant. 17.4.2 §78); the Pharisee Rabban Simon ben Gamaliel (War 4.3.9; §§159-61; Life $38 \S 190,60 \S 309$ and passim); and Simon bar Giora, the son of a convert and a leader in the war against Rome (War 4.9.3-8 §§503-29). Several of these figures are also known from the Books of Maccabees and from rabbinic literature; the latter in turn features at least fifteen Tannaitic rabbis called Šmion, the most prominent of whom are Simeon ben Gamaliel and Simeon ben Yohai. Even the New Testament itself knows nine or ten men of that name. ${ }^{14}$ All in all, Tal Ilan's Lexicon of Jewish Names in Late Antiquity lists 258 individuals named Simon. ${ }^{15}$

Simon Peter's first Jewish name is therefore hardly out of the ordinary. This makes it all the more remarkable, however, that despite its patriarchal origin virtually all other known individuals of that name date from the second century BCE or later. Thereby, of course, hangs an important tale that remains remarkably unfamiliar to most students of the New Testament.

\footnotetext{
11 Developing a suggestion of John Chrysostom (Hom. 33 on Acts 15), Riesner 1994 argues that the 'Simeon' of Acts 15:14 is the same as in Luke 2:25-35. But the more natural reference is to 15:7-James's $\pi \rho \hat{\omega} \tau o \nu$ suitably reflects Peter's $\alpha \dot{\phi}$ ' $\dot{\eta} \mu \rho \hat{\omega} \nu \nu \alpha$ d $\rho \chi \alpha i \omega \nu$, just as the Gentiles' 'hearing' and 'believing' the Gospel represents their being accepted by God as his people.

12 So e.g. Bagatti 1953, citing the index in Niese 1885:7.564.

${ }^{13}$ For a brief discussion of the chronological problems surrounding Simeon the Just, raised in part by the conflict between Sir. 50:1-21 and Josephus' doubtful claim in Ant. 12.2.5 \$43 that he lived under Ptolemy I (c. 300 BCE), see e.g. Stemberger 1996:63.

14 Cf. e.g. the lists in $O D C C$ 1500, 1504; BDAG s.v.

15 Ilan 2002 lists 257 in the main text and one in the addendum, p. 449.
} 


\section{Biblical Disappearance}

Following its patriarch's unflattering exploits in the book of Genesis (Gen. $34 ; 42: 24,36 ; 43: 23)$, the tribe of Simeon appears to enjoy only a brief walkon part in the subsequent history of Israel. Having apparently settled in the Negev on a part of Judah's allotted inheritance (e.g. Josh. 19:1; 1 Chr. 4:2833; cf. Judg. 1:3, 17), the Simeonites continued in a semi-nomadic existence and soon became almost wholly subsumed within the tribe of Judah. Between the first and the second census in the book of Numbers the tribe of Simeon loses over $60 \%$ of its population (Num. $1: 23 ; 26: 14$ ). It is the only one of the twelve tribes to be omitted from Moses' blessing in Deut. 33, and it produced no judges or kings. The Chronicler professes to trace Simeonite genealogies as late as the eighth century (1 Chr. 4:24-43) and to identify 'cities of Simeon' in the seventh. ${ }^{16}$ Some later rabbinic texts claim, perhaps for apologetic reasons, that the genealogy of the Simeonites was based on the records they kept. ${ }^{17}$ But even if one were to accept all this at face value, the Old Testament links no-one after the eighth century BCE with the tribe of Simeon. And the only biblical re-appearance of the personal name after the patriarch is in an obscure man in the book of Ezra who agreed to divorce his foreign wife (Ezra 10:31; cf. 1 Esdr. 9:32). ${ }^{18}$ It is true, of course, that the names of the Patriarchs were not generally used as personal names until after the exile; Levi, too, for example, remains unattested until Maccabean times. ${ }^{19}$

\section{Eschatological Reappearance}

At the same time, eschatological hope for the restoration of Israel kept alive the memory of Simeon and the expectation of this tribe's return to prominence. In Ezekiel, at Qumran and in the Book of Revelation, the twelve gates of the New Jerusalem include one for Simeon. ${ }^{20}$ This corresponds to a noticeable revival of Simeon's fate in other works of the later Second Temple period. Thus the Testaments of the Twelve Patriarchs include Simeon as a man of extraordinary strength and voice (Test. Sim. 2.3), while the Lives of the Prophets assign the biblical prophets Nahum (11:1) and Habakkuk (12:1) to the tribe of Simeon. The Book of Judith identifies a magistrate as belonging to that same tribe (6:15), while the heroine herself appeals to the 'Lord God of my

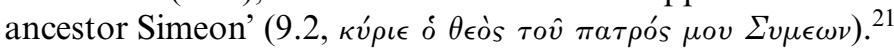

Peter's first name, therefore, reflects an astonishing resurgence of the name Simeon since the second century BCE. From being virtually extinct it came to be 'one of the most widely used names for Palestinian male children of

\footnotetext{
162 Chr. 34:6 (apparently situated in the North).

17 E.g. Num. Rab. 13.8; cf. Ginzberg 1967:6.83.

18 One wonders about Luke's inclusion of an otherwise unattested 'Simeon son of Judah' in his genealogy of Jesus (Luke 3:30), seven generations after David's son Nathan. Jeremias 1969:296 suspects this to be a historically worthless anachronism.

19 On this point cf. Jeremias 1969:296 and n. 94.

20 Ezek. 48:33; 4Q554 1.i.13; 11QTemple 39.12-40.14; 44.4, 9; cf. 11QTemple 24.14; 11Q20 8-9.ii.13; Rev 21:12; cf. 7:7.

${ }_{21}$ For other references in the DSS see e.g. 4Q364-365 25.11; 4Q522 6.1; 3Q7 5+3.2-3; 4Q245 1.i.9.
} 
the period'. ${ }^{22}$ While it is of course true that 'Simeon' was a name whose close Greek equivalent 'Simon' made it particularly convenient in a bilingual culture, this alone would hardly suffice to account for its popularity. ${ }^{23}$ No doubt boosted by famous leaders like Simeon the Just and Simon Maccabaeus, it may have been precisely the Hasmonean atmosphere of national restoration and expansion which lent itself to the revival of long-forgotten personal names symbolic of Israel's identity and constitution. The aggressive re-Judaisation of Idumaea, Galilee and Ituraea ${ }^{24}$ may well be another dimension of this: the Hasmonean vision of restoration, similar to that later expressed by the Psalms of Solomon, explicitly required the Land to be inhabited by Jews living by Jewish law. ${ }^{25}$

\section{Simon Called Peter}

What follows from all this for Simon Peter? Not very much, perhaps: neither Simeon the patriarch nor his descendants were of special significance in the Jesus movement; and we have no particular reason to suspect a deliberate link with Peter. ${ }^{26}$ What is more, the less common nickname 'Peter' in itself suggests the need to distinguish him from the increasing numbers of others, even among the family and followers of Jesus, who shared the same patriarch's name. ${ }^{27}$ Nevertheless, in the late first century BCE the historical context of the name Simon may well have retained a residual significance in the case of a boy born into a Jewish family resident in the highly Hellenised Gentile village of Bethsaida east of the Jordan. ${ }^{28}$ Unlike his brother Andrew, who has few rabbinic namesakes, ${ }^{29}$ Simon bore a pedigree Jewish name that remained in use throughout the rabbinic period.

\section{Bar Yonah: A Galilean Patronym}

A somewhat more familiar topic of discussion is Peter's apparent patronym,

\footnotetext{
22 Fitzmyer 1998:113-14; cf. previously Fitzmyer 1971 and note further Ilan 2002 s.v.

23 One might on this principle expect an analogous proliferation of Isocrates for Issachar, Zenon for Zebulon, etc., but this is not the case.

${ }^{24}$ This was successively pursued by Simon Maccabeus and Aristobulus I; it is also worth considering the Galilean campaign of Herod the Great and the return of Jewish rule for the last time after Nero ceded Galilee to Agrippa II c. 61 CE (cf. Schürer 1973-86:1.473, n. 8).

25 The policy in each case is clearly identical and carefully framed: cf. Josephus Ant. 13.9.1

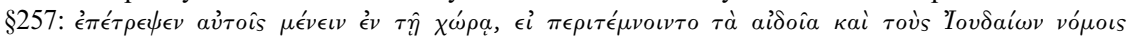

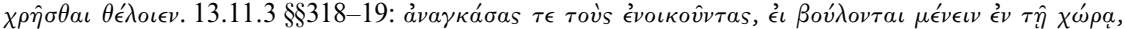

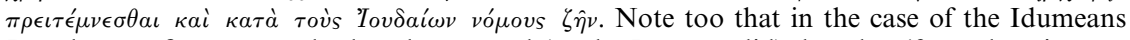
Josephus confirms not only that they agreed (as the Itureans did), but that 'from that time on

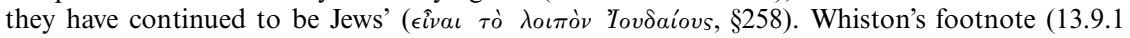
$\$ 257, \mathrm{n}$. 25) suggesting a possible link between the Idumeans and the land of the Simeonites is geographically plausible, but lacks corroborating first-century evidence.

26 Unless one wanted to see a connection with the patriarch's impetuous violence and physical strength in biblical and post-biblical treatments; but this is never made explicit.

27 Cf. e.g. Mark 3:18; 6:3; cf. 14:3; 15:21, etc.

28 On Bethsaida see e.g. Arav and Freund 1995-1999.

29 But note reference to the wealthy family of Bar Andrai in y. Ket. 9, 33a15; also R. Hinenah bar Andrai in y. Ber. 1.1, 2c24; cf. y. Meg. 4.5, 75b36.
} 
Bapıwva. It remains a widespread critical assumption that this means 'Son of Yonah', which in turn abbreviates 'son of Yohanan' i.e. 'son of John'. As major commentators point out, however, there are a number of problems with this identification.

\section{Yonah-A Name of the Second Temple Period?}

The New Testament's only use of Bapıwva is in its untranslated form in Matthew 16:17. That 'Yonah' might be a Hebrew name at this time has sometimes been doubted, but it was clear to many of the ancient Christian writers. Some parts of the Greek and Latin manuscript tradition space out 'Simon Bar Yona' (B⿱亠幺 $\rho$ ' $\hat{\omega} \nu \alpha)$ at Matt. 16:17. ${ }^{30}$ The same is true for a number of church fathers, including the fifth-century Basil of Seleucia, whose Sermons assume as uncontroversial that Bariona means 'Son of Yona'. ${ }^{31}$ An extensive and early tradition of textual variants in John reads 'Simon son of Yona' (viòs 'T $\hat{\omega} \nu \alpha$ ) in John 1:42 ${ }^{32}$ and simply 'Simon (of?) Yona' in 21:15-17. ${ }^{33}$ This may of course be due to Matthean influence: Joachim Jeremias summarily discounted all the Johannine textual variants as deriving from Matthew 16:17. ${ }^{34}$ A certain amount of cross-contamination in the textual tradition is indeed plausible, although Donald Hagner is right to note the absence of a corresponding Johannine influence on the Matthean variants. ${ }^{35}$ However one decides this issue, the Johannine variants do confirm the widespread understanding that Yonah is a name. The Peshitta, too, corroborates that conclusion by reading 'son of Yona' throughout.

A number of other well-known problems cloud this identification of Peter's father as Yonah, quite apart from the fact that we know nothing else about him. No male individual called Yonah is directly attested in Jewish literary sources between the biblical prophet and the third century CE, although $J u$ bilees 34.20 refers to Asher's wife by that name (i.e. 'dove') and the Mekhilta de-Rabbi Ishmael may contain a passing reference to the wife of a Tannaitic individual called Yonah. ${ }^{36}$ We do, however, know of a few Amoraic rabbis called Yonah. These include the obscure R. Yonah bar Tahlifa, apparently from Babylonia, ${ }^{37}$ but also R. Yonah of Bozrah in Batanaea (Southern Syria), a city of note for Jewish, Christian and Muslim history. ${ }^{38}$ By far the most

$30 \Lambda \Gamma$ and numerous minuscules. In the Vulgate tradition, 'son of Yona' (filius Ionae) appears in the 1529 Wittenberg edition at Matthew 16:17 and in the authoritative 1592 Rome ('Clementine') edition at John 1:42.

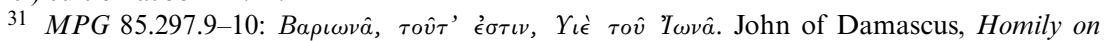

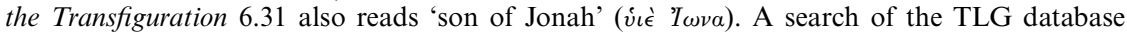
(23.7.2002) returned patristic readings of $\beta a \rho$ i $\omega \nu \alpha$ in Eusebius $(7 \times)$, Athanasius $(1 \times)$ and Chrysostom $(1 \times)$.

${ }^{32} \mathrm{NA}^{27}$ lists A B $\Psi f^{1.13}$ and the Majority Text. Similarly Basil's Comm. In Is. 5.169.

33 A C $^{2} \Theta \Psi f^{1.13} 33$, Majority text and Peshitta.

34 Jeremias 1938:410, n. 2.

35 Hagner 1993-95, ad loc.

$36 \S 68$, cited and discussed in Ilan 2002:143-44. She notes (p. 144, n. 5) an apparent connection with pilgrimage and therefore dates the individual confidently before 200 .

37 b. Hul. $30 \mathrm{~b}$

38 E.g. Lev. Rab. 8.1.3, Pesiq. Rab. Kah. 2.4. On Bozrah or Bostra cf. further 1 Macc. 5:26; 
famous Rabbi Yonah, however, was joint leader of the academy of Tiberias during the revolt against Ursicinus, i.e. c. $351 \mathrm{CE}$, and is frequently cited in the Palestinian Talmud and Midrashim. ${ }^{39}$ Among his sons was Menahem, who taught in Sepphoris and whose name is usually abbreviated to Rabbi Mana or Mani; ${ }^{40}$ another son may have been Samuel bar Yonah. ${ }^{41}$ The apparent Galilean connection of the name is potentially of interest, as may be the biblical prophet Jonah's origin in Gath-hepher near Sepphoris. ${ }^{42}$ Inscriptional evidence, on the other hand, confirms the use of the name Yonah in Spain, Gaul and Egypt. ${ }^{43}$

Most interesting for our purposes, perhaps, is the widely ignored existence of an Amoraic Palestinian Rabbi Śimon bar Yonah, conceivably a son of the same man. He appears in a passing reference in Genesis Rabbah, where he interprets Psalm 12:6 as signifying that God will rouse himself to save Jerusalem at the end of time. ${ }^{44}$ Nothing else is known of him, and his relation to the famous fourth-century rabbi remains conjectural. Conversely, a third or fourthcentury Beth She'arim funerary inscription in Greek has the name 'Yonah son of Simon'. ${ }^{45}$

\section{Peter as Jonah Redivivus?}

Writing in 1938, the German New Testament scholar Joachim Jeremias came to a cautious and tentative conclusion about the balance between the gospel evidence, which points to Yonah as an abbreviation of Yohanan (i.e. John), and the possibility that isolated instances of the biblical name Jonah recurred from time to time. In the supposed absence of Yonah as a contemporary name, a number of interpreters have from time to time picked up on this latter connection. That would identify the Yonah of 'bar Yonah' with the biblical prophet, who appears in Matt. 12:39-41 and again in 16:4 shortly before our passage, as the only Messianic sign Jesus is prepared to offer: 'as Jonah was three days and three nights in the belly of the whale, so will the Son of man be three days and three nights in the heart of the earth.' On this reading, 'Jonah' is simply Matthew's preferred prophetic symbol for the Messiah; and Peter's identification as 'son of Jonah' thereby symbolises his seal

by the third century CE the city was a Christian bishopric and the site of important synods. Origen stayed here twice. The Didascalia is sometimes said to have been composed here. A Muslim tradition relates that Mohammed received instruction in Bozrah from a Christian monk called Bahira or Sergius. See further Colpe 1975; Hübner 1992.

39 Cf. Stemberger 1996:95-96 and most fully Bacher 1892-99:3.220-31, with numerous references. Yonah is most frequently cited in Genesis Rabbah, Leviticus Rabbah and the Palestinian Talmud.

40 See Stemberger 1996:96.

41 Y. Meg. 1.4, 70d26; Gen. Rab. 5.7; Lev. R. 30.3; Pesiq. Rab. Kah. 27.3. Note also v. l. R. Abba bar Yonah for R. Abba bar Zemina at $y$. Š eqal. 5.1, 48c (bottom).

422 Kgs. 14:25; also noted by Thiede 2000:23.

43 Noy 1993-95:1:187 (=CIJ 12:660d)-Noy interprets Ionati as a form of Iona, p. 261; 1:191 (=CIJ 12:671); CPJ 1:35, line 18 .

44 Gen. Rab. 75.1, ר' שמעון בר יונה.

45 Schwabe and Lifshitz 1973:197, no. 215. 
of Messianic approval — making Peter the 'Messianist' par excellence. ${ }^{46}$ But if Matthew were indeed engaged in such fancy midrashic footwork, we would not expect him to undermine his own redactional purpose by concealing this gem from his Greek-speaking readers by means of a word game that works only in Aramaic. Conversely, as soon as Bar Yonah can be shown to be a standard Galilean patronymic, intelligible to anyone resident in Syria, the likelihood of free-floating allegorical wizardry may recede into the background. ${ }^{47}$

\section{'Son of Yonah' or 'Terrorist'?}

One other, more interesting interpretation of Bar Yonah has been offered from time to time, impelled once again by the supposed implausibility of that patronymic. Robert Eisler, followed by Hirschberg, Cullmann and others, argued that this term is not a patronymic at all, but should instead be interpreted as the Aramaic term בריונא, a word related to בריון, 'soldier', which could at times denote a 'rebel' or indeed a 'terrorist'. ${ }^{48}$ On somewhat similar grounds, Gerd Theissen has argued the unsubstantiated interpretation of 'bar Jonah' as someone who lives 'on the fringe of society'. ${ }^{49}$ The term בריון does indeed function in this way in certain rabbinic texts, some of which carry early attributions. It is, for example, used of the militants in Jerusalem who refused appeals to make peace with the Romans during the War against Rome (b. Git. 56a הנהו בריוני). Rabban Yoḥanan ben Zakkai's nephew Abba Siqara was said to have been 'chief of the rebels of Jerusalem' (b. Git. 56a, (ריש בריוני דירושלים -and, ironically, to have advised his uncle on fleeing the city in a coffin. Elsewhere, however, the term may simply denote ordinary thugs or hooligans, like those who used to trouble R. Meir on one occasion. ${ }^{50}$ To associate Simon Peter with nationalist thuggery would certainly suit the recurring critical trajectory of reading the ministry of Jesus in militant nationalist terms, a trajectory whose key co-ordinates range from Reimarus via Robert Eisler to S. G. F. Brandon. ${ }^{51}$ Simon Bariona might on this account be related in more than just name to Simon the Zealot, though even then he could hardly have been identical with him. The fact is that the term baryon (or biryon) remained untypical as a description of zealots, and is not usually

${ }^{46}$ See most recently Diebner 1998; cf. previously Robinson 1984; Brown 1987:37 argues for Peter as the 'Son' of Jesus the new Jonah, while Wall 1987 extends the symbolism to Peter's dealings with Cornelius and the Gentile mission. See further Gundry 1994:331-32, also endorsed by Thiede 2000, 279, n. 16; and cf. Davies and Allison 1988-97:2.622 as well as Hagner 1993-95 ad loc.

47 The doubt expressed about prophets from Galilee in John 7:52 seems to raise additional difficulties for any supposedly self-evident correlation with the biblical prophet Jonah: see $2 \mathrm{Kgs}$. $14: 25$ and $n .42$ above.

48 So notably Hirschberg 1942, for whom Simon Bariona is the same as Simon the Zealot (cf. the linguistic response offered by Marcus 1942); Eisler 1929:2.67-68. Cullmann sounds mildly sceptical in Cullmann 1962:22-23, but more positive in Cullmann 1963:16-17 and Cullmann 1970:9 and n. 13. Key rabbinic texts on the בריונים include b. Git. 56a-b and b. Ber. 10a.

49 Theissen 1978:11.

${ }^{50}$ E.g. b. Ber. 10a: certain thugs in that area, הנהו בריוני דהוו בשכבותיה; cf. b. Sanh. 37a; b. Ta'an. 23b.

51 More recently, Chilton 2001:81-82 appears sympathetic to Brandon's perspective; cf. also Chilton 2000. 
linked with Peter or any other Jewish Christians. ${ }^{52}$ And despite some early attributions the evidence for the actual usage of baryona seems to be relatively late - and arguably sardonic (and metonymic) rather than plainly descriptive. Its relevance to Simon Peter is far from obvious. All in all, such an association sheds little light on what for all sorts of other reasons is much more likely to be a straightforward patronymic. ${ }^{53}$

\section{John or Yonah?}

Another question to be addressed in this connection is the correlation between the names Yonah and Yohanan, noted above with reference to Jeremias. The Fourth Gospel has Jesus addressing Peter as 'Son of John' on four occasions $(1: 42 ; 21: 15,16,17)$, while the Gospel of the Nazarenes may also have read 'Simon son of John' at Matthew 16:18, although at 19:24 it has Peter addressed as 'Simon son of Yonah'. ${ }^{54}$ But there is no other confirmation of the idea that Yonah was short for Yohanan. Rabbinic literature amply attests that the standard Palestinian abbreviation of Yohanan was Yohai, while offering no evidence for Yonah as an abbreviation..$^{55}$ On the very rare occasions where the name Yonah does appear in Jewish inscriptions of the period, it seems most likely to stand for Jonathan, if indeed it is an abbreviation at all. ${ }^{56}$ The Peshitta's consistent reading Yonah in both Matthew and John also raises questions about the straightforward interchangeability of Yohanan and Yonah.

The Jewish evidence in favour of such an identification remains slim. A number of variants in the Septuagint manuscript tradition do show that that the equation of John with Jonah is at least attested, contrary to a passing assertion by Oscar Cullmann. ${ }^{57}$ But these Septuagintal readings are admittedly difficult to date and locate with confidence. ${ }^{58}$ At least one Talmudic tradition transmitted in the name of R. Yonah appears to surface elsewhere under the name of R. Yohanan, ${ }^{59}$ but this again seems insufficiently strong evidence on

\footnotetext{
52 One exception is Midrash Tehillim on Ps. 104:27: instead of 'certain thugs' in R. Meir's neighbourhood בריוני הנהו, this midrashist reads 'a certain min' ההוא מינא, i.e. a (potentially Jewish Christian) heretic.

53 See the careful discussion in Hengel 1989:54-56.

54 Frg. 14 (=frg. 9 ed. Klostermann, as cited in Jeremias 1938:410). The reference is to NT codices 566 and 1424, two MSS of the so-called Zion Gospel Edition, which refer in marginal

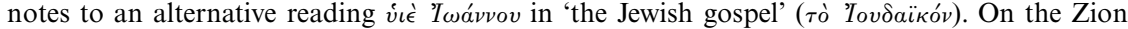
Gospel Edition see Petersen 1992; also Klijn 1992:25. For the reference at Matt. 19:24 see Gos. Naz. 16 (Origen Comm. on Matt., 15.14).

55 Cf. Dalman 1905:179, n. 5.

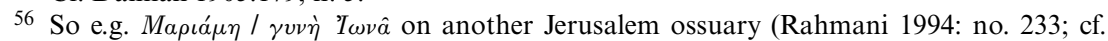
also Ilan 2002:143). Rahmani appeals to CPJ 1:181 no. 35, line 18 in suggesting that the close

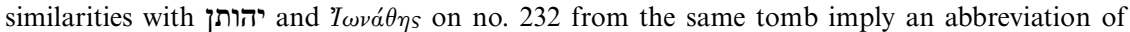
the latter name. Another first-century inscriptional attestation of the name Yonah occurs on an ossuary from Issawiya, $C I J$ no. 1245 (see Fitzmyer and Harrington 1978: no. 134 (cf. note on p. 244); Ilan 2002:143-44).

57 Cullmann 1963:16 ('no documentary evidence for Jona as an abbreviation for Johanan').

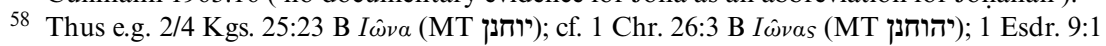

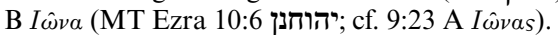

59 See Bacher 1892-99:1.451, n. 2.
} 
which to base an assumption that the names are the same. The attribution of a tradition to two different rabbis is a common phenomenon, and there are other examples involving R. Yonah. ${ }^{60}$ All in all, then, the primary evidence for the identification of Bariona as 'son of John' remains that of the Fourth Gospel, possibly together with one passage of the Gospel of the Nazarenes; elsewhere it is found only in later Christian sources. On the available evidence we must allow for the possibility that John 1:42 single-handedly accounts for the notion that Yonah abbreviates John.

\section{Simon Bar Yonah's Ossuary in Jerusalem?}

In view of the sensational media interest associated with the supposed ossuary of James the brother of Jesus in 2002, it is worth taking the wind out of the sails of another hypothesis involving Simon bar Yonah, first advanced by a swashbuckling anti-Catholic crusader from Indiana on the basis of a littleknown archaeological discovery half a century ago in Jerusalem. Although largely forgotten by the scholarly community, this theory is still remarkably widely promoted on the internet and in popular publications to this day. ${ }^{61}$ Briefly put, F. Paul Peterson argued that ossuary inscriptions found in the 1953 excavations on the Mount of Olives prove Simon Peter to have been buried in Jerusalem rather than in Rome - a theory that some German scholars had previously advanced on other grounds. ${ }^{62}$ Bellarmino Bagatti's initial announcement of these discoveries near the Dominus Flevit church in 1953 had indeed suggested that Inscription 11 should be read 'Simon son of Jonah', The transcription (on the next page) shows that this is at least conceivable.

What gave this discovery additional intrigue in the eyes of conspiracy theorists was Bagatti's general over-enthusiasm to identify archaeological evidence of Jewish Christianity. In this particular case, he interpreted apparent cross and chi-rho symbols on certain ossuaries as indicating a definite 'JewishChristian cemetery'. ${ }^{64}$ Others soon pointed out that there are a number of equally plausible alternative explanations. ${ }^{65}$ To be sure, a survey of the names that turned up on the Dominus Flevit ossuaries makes it easy to understand the temptation to find links with known figures of the New Testament: in their Anglicised forms these names include inter alia Lazarus, Jairus, Martha and Mary on the same inscription, Matthias, Sapphira, Zechariah and indeed

60 On the problem of 'migrating logia' see e.g. Stemberger 1996:57-59; cf. further Bacher 1892-99:3.220-31 on R. Yonah.

${ }^{61}$ See Peterson 1960, frequently reprinted. Full text online at www.acts2.com/thebibletruth/ Peters_Tomb.htm (last accessed 14 March 2003); frequent citations elsewhere; e.g. in Gilman 1998, reproduced even in a seemingly mainstream popular Christian journal site like http:// www.leaderu.com/theology/burialcave.html.

62 E.g. Erbes 1901, with a reply by Kneller 1902.

63 Bagatti 1953:162.

64 'Cimitero giudeo-cristiano', Bagatti 1953 passim.

65 Bagatti 1953; cf. the review of Bagatti and Milik 1958 by Avi Yonah 1961; also van der Ploeg 1960. For the cross marks see more fully Smith 1974. The critique of Bagatti and other Franciscan archaeological attempts to unearth 'Jewish Christianity' is most sharply developed in Taylor 1993. 
Jesus. A comparison of Dominus Flevit with similar ossuary collections from nearby Silwan and Talpiot shows merely that the names of first-century Judaean Christians were characteristic of their time and place, inasmuch as they occur with about the same frequency in the New Testament and in contemporary Jerusalem funerary inscriptions. ${ }^{66}$ Certainly the name 'Simon' appears on ossuaries several dozen times. ${ }^{67}$

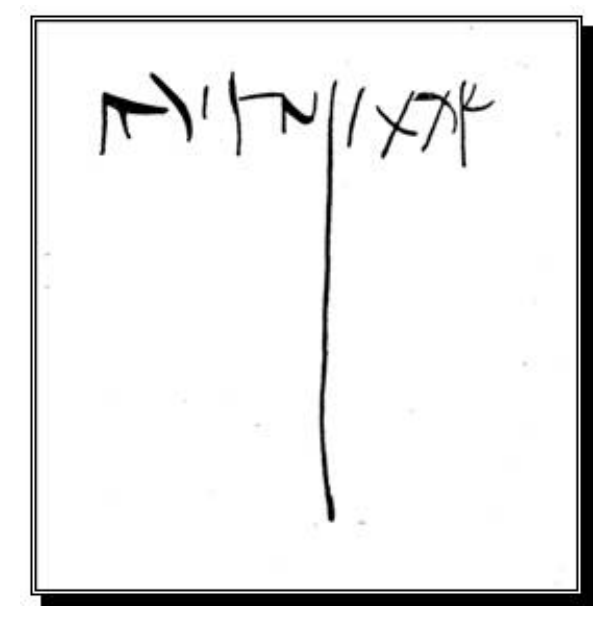

By the time J. T. Milik published the inscriptions in the official publication report released in 1958, he had arrived at a rather more modest conclusion about Inscription 11. While the reading Šim 'on bar Yonah remained in his view theoretically possible, a number of quite different readings were just as likely. Even the number of letters in the last word was uncertain and not one of them could be read with confidence. Noting the abnormal shapes of both nun and $h e$, together with the fact that the ossuary was inscribed with a piece of coal rather than incised with a nail, Milik suggested that the two leftmost vertical lines of the he may in fact represent a poorly executed single down-stroke of an uneven (concave?) piece of coal, a phenomenon comparably attested elsewhere in the same cemetery. ${ }^{68}$ As a result, his reading offered merely three unidentified letters (i.e. '...'). ${ }^{6}$

Others have concurred in offering a comparably reserved judgement. ${ }^{70}$ Since the ossuaries in question date primarily from the early first century CE,

\footnotetext{
66 Cf. Finegan 1992:246.

67 Milik already knew of 32 such instances in 1958 (Bagatti and Milik 1958:77).

68 E.g. p. 86, fig. 22, Nos. 6-7.

69 Milik in Bagatti and Milik 1958:83; he suggests that זינה is equally possible.

70 Fitzmyer and Harrington 1978: no. 72 were only marginally more sanguine in offering ה שמעון בר . Finegan 1992:245 continues to allow for Yonah. Since the Dominus Flevit ossuaries are held in the museum of the Studium Biblicum Franciscanum (see http://198.62.75.1/ www1/ofm/sbf/SBFmain.html), they are unfortunately not discussed by Rahmani 1994.
} 
an identification with Simon Peter is in any case impossible. ${ }^{71}$ On the other hand, even if for the sake of the argument one were to accept the reading 'Simon bar Yonah', we would find here a name that would strike contemporaries as unremarkable in the first century as much as in the third or fourth.

\section{Cephas}

Peter's Aramaic name Kêf $f a^{\prime}$ has been the subject of far more extensive discussion, partly because its ecclesiological significance was for a long time deeply contested between Catholic and Protestant interpreters. The blossoming of ecumenical dialogue and of Roman Catholic biblical studies since Vatican II has meant that the confessional wind has for some time been more conducive to genuine progress and consensus. The exegetical dividing lines no longer fall along predictably denominational lines. The meaning of the Aramaic term כיפא as 'rock' or 'crag' has been reasonably demonstrated in the Targums and Dead Sea Scrolls, ${ }^{72}$ although the implications are still ignored by some recent commentators who deny that $k \bar{e} f a$ ' could be something one builds upon. ${ }^{73}$ This is not of course to say that all the difficulties have been removed. One of the major disagreements concerns the authenticity of Jesus' saying about Peter as the Rock in Matthew 16:18; on this matter the major multi-volume commentaries of the last decade continued to reach opposing conclusions. Another abiding problem is the significance of the wordplay employed in that verse.

For present purposes, the answer to the problem of historicity is relatively unimportant. On the more focused question of what the name Cephas might mean to a Jewish audience of the early rabbinic period, answers are more readily to hand and probably on balance less controversial.

We may here discount the suggestion of Clement of Alexandria, occasionally revived on more critical grounds by a small number of scholars, that the Cephas of Galatians 1-2 is not Simon Peter but someone else. ${ }^{74}$ Clement's rationale, subsequently adopted by Jerome, seems quite patently an apologetic counsel of convenience with respect to an episode that other patristic writers found equally embarrassing. ${ }^{75}$ The primary critical argument derives from Gal. 2:7-8, where Paul unexpectedly shifts from his otherwise exclusive usage of 'Cephas' in order to refer to 'Peter'. But the Fourth Gospel is quite clear that Cephas is the same as Peter (John 1:42), and the surprising fluctuation of these two names in the manuscript tradition of Gal. 1-2 also suggests that

71 See Bagatti and Milik 1958:70-109; also cf. Finegan 1992:244; Fitzmyer and Harrington 1978:225.

72 11QtgJob 32.1; 33.9; 4QEne 4.iii.19; 4QEnc 4.3; 4QEn ${ }^{\mathrm{a}}$ 1.ii.18. See Fitzmyer 1998:115.

73 E.g. Luz 1985-2002 ad loc., following Lampe 1979.

74 So Hyp. 5 in Eusebius Eccl. Hist. 1.12.2: Clement claimed this Cephas was one of the Seventy. The most recent advocate of the differentiation was Bart Ehrman 1990, who was swiftly and effectively answered by Dale C. Allison 1992. Cf. previously Lake 1921, and see Fitzmyer $1998: 121$, n. 15 for other earlier representatives.

75 Jerome, Ep. 86-97 and Chrysostom, Hom. Gal. 2.1 suggest that the apostles merely staged their dispute as an object lesson to the faithful. 
ancient writers on the whole assumed them to be identical. ${ }^{76}$ The immediate context of Galatians 1-2 is equally unambiguous in affirming that Cephas is the most important apostle and pillar of the Judaean church, whose sole acquaintance Paul seeks out in Jerusalem (1:17-18) — in other words, the figure of whom it might most reasonably be said that he was the key 'apostle' for 'the gospel to the circumcised' (2:8-9).

Cephas, then, is Peter. What is more, the application of this name to Simon is now widely regarded as dating back perhaps to an early stage of his association with Jesus, ${ }^{77}$ some of whose other disciples bore comparable epithets. ${ }^{78}$ Interestingly, Jesus' only reported use of either form of 'Peter' as a proper name addressed to Simon occurs at Luke 22:34, where it is probably redactional. It seems likely, nevertheless, that both Kéf $a^{\prime}$ ' and its equivalent, П'́t were in use in their respective linguistic settings from the very beginning of the Christian movement. Simon's brother, by contrast, seems to bear only the

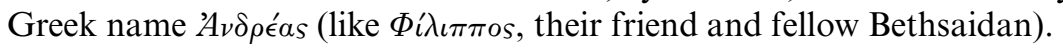

But what resonance might these appellations have among a contemporary Jewish audience? Cephas is not attested as a non-Christian personal name in Hebrew or Aramaic sources from the Second Temple or rabbinic periods. True, Joseph Fitzmyer has rightly drawn attention to the existence of the name $K \bar{e} f a$ ' in a fifth-century Jewish Aramaic papyrus from Elephantine in Upper Egypt ${ }^{79}$ comparing it with the Hebrew name Sur ('rock') which is repeatedly attested in the Old Testament. ${ }^{80}$ But it remains the case that nearly half a millennium of history and culture separates Elephantine from first-century Palestine, where the evidence suggests that Cephas was not current as a name. ${ }^{81}$

The term Cephas would have remained perfectly intelligible in Jewish circles throughout the rabbinic period, so that the name Sim 'ōn Kêfa' could still be readily understood and interpreted in the later legends of the Toledot $Y e s h u .{ }^{82}$ In the absence of evidence for Cephas as a Jewish name, however, this remains as Peter's most distinctive epithet-his nickname rather than a proper name. ${ }^{83}$ Somewhat contrary to Fitzmyer's inquiry, it seems likely to have been of interest precisely because it was not a familiar personal name.

\footnotetext{
76 See the documentation in Fitzmyer 1998:121, n. 17.

77 So Mark 3:16; John 1:42; Matt. 16:18 (cf. Matt. 10:2) has been taken to assume a later, more specific setting, which in its present form does have obvious overtones of post-Easter concerns. A minority of Protestant scholars has somewhat implausibly attempted to seek the origin of the name entirely after the resurrection: so e.g. Dinkler 1961; Conzelmann 1965, partly based on the future tense $\kappa \lambda \eta \theta \dot{\eta} \sigma \hat{\eta}$ in John 1:42.

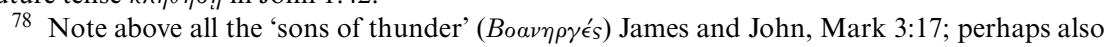
Thomas $\Delta i \delta v \mu o s$ (John 11:16; 20:24), although the latter does not appear to be an Aramaic name.

79 Fitzmyer 1998:116-18, citing BMAP 8.10: ' $q b$ br kp'.

801 Chr. 8:30; 9:36; Num. 25:15; 31:8; Josh. 13:21.

81 In view of periodic scholarly confusion on this point, it is worth noting that the inscription from the so-called tomb of Caiaphas contains the name קפא (also spelled קופא / קיפא -not כיפא. This pertains whether or not the occupant's identification is correct: cf. Reich 1992 and Greenhut 1992, and the critique by Horbury 1994. Schlatter 1930:56 claims a 'probable' Galilean spelling קיף, but adduces no evidence.

82 See Krauss 1902 passim; cf. Str-B 1:530-35.

83 So also Ilan 2002:436, n. 3. She also (n. 1) cites G. L. Harding in support of kpy as a name in pre-Islamic Arabic.
} 
It is this that characterised him in the Aramaic-speaking churches of Judaea, and which ironically survived even Paul's move into the Gentile world.

\section{Peter?}

This evident silence of the sources on Cephas as a name, together with the supposed impossibility of using it for a meaningful Aramaic word play underlying $\pi \epsilon^{\prime} \tau \rho o s$ and $\pi \epsilon \epsilon \rho \alpha$, has commonly been adduced as an argument that the discourse in Matt. 16:18 cannot be based on an underlying Aramaic or Hebrew original. ${ }^{84}$ In 1956 Oscar Cullmann speculated that Peter may have carried both the Greek and the Aramaic name - a possibility made more plausible by the Greek names of Peter's brother Andrew and his friend Philip, both of whom also hail from the Greek-speaking environment of Bethsaida. ${ }^{85}$

\section{Petros as a Jewish Name?}

But it remains desirable to ask what Jewish dimensions, if any, this name is likely to have had. ${ }^{86}$ And is it conceivable that even the Greek name could have featured in a Hebrew or Aramaic source? It is after all only John 1:42 which, on a certain reading, might be taken to suggest that 'Peter' is a secondary translation of an existing name $K \bar{e} f a$ '. It is instructive to note, however, that two verses earlier the evangelist seems to undermine even this conventional assumption of the priority of 'Cephas' by referring casually to 'Simon Peter' (1:40). Taken at face value, the text implies that it is this Simon, nicknamed Petros, who from now on 'shall be called Cephas'. All four gospels, indeed, allow for the possibility that Matthew 16 merely affirms and interprets in Aramaic an existing Greek nickname that Peter had all along. ${ }^{87}$

Some years ago James Charlesworth suggested the possibility that the name Petros might have turned up in the controversial Dead Sea Scrolls fragment $4 \mathrm{Q} 341,{ }^{88}$ although both his reading and the identification of this document as a medical text were quickly rejected by Joseph Naveh and others. ${ }^{89} \mathrm{Re}-$ gardless of Charlesworth's text, however, the currency of Peter's name is confirmed in Tal Ilan's identification of three additional first and second-century

\footnotetext{
${ }^{84}$ Cf. again Fitzmyer 1998:119, who makes a somewhat half-hearted attempt.

85 Cullmann 1956:99; cf. recently Thiede 2000:66-67; on Bethsaida more generally see Bockmuehl 2003:3 (forthcoming).

86 So also Thiede 2000:66.

87 See Mark 3:16; Matt. 4:18; Luke 5:8; John 1:40, 42.

88 Line 8 . The document was first published as the supposed medical text 4QTherapeia by Allegro 1979:235-44 and pls. 16-17, and re-edited under the same name by Charlesworth 1985 . Naveh 1986 decisively queried both the identification of a medical genre and the proposed reading פיטרוס, which was re-affirmed in Charlesworth 1992 (with minimal response to Naveh) and accepted e.g. by Thiede 2000:67 with 291, n. 100 (and more tentatively by Bivin 1994:38, n. 17).

89 Naveh 1986, widely followed, identifies the text as a writing exercise and reads line $9 \mathrm{~b}$ as יטריסיסי; cf. more recently Naveh 2000 (his official publication of the text in DJD). Charlesworth 1987 retracted his earlier view that 4Q341 is a medical text (cf. Charlesworth 1992:219-20), although he persists in reading the first word of line $9 \mathrm{~b}$ together with the last letter of the previous line, as פן פיטרוס (confirmed in a personal conversation, 8 August 2002).
} 
Palestinian Jewish individuals who bear the name Petros..$^{90}$ It is worth noting that the Palestinian Talmud and midrashim repeatedly feature an early Amoraic Rabbi Yose ben Petros, whose father constitutes proof that even this Greek name was by no means unknown in the early rabbinic period. ${ }^{91}$ A Jewish convert called Petrus also appears in a fifth-century Christian inscription from Grado in Italy. ${ }^{92}$

\section{Matthew and Midrash on Petros and Abraham}

At this point we must also reconsider a poorly understood hypothesis about Matthew 16:18 that carries definite interest for our topic, even if it may not bear on the exegesis of that passage in the way commentators have supposed. Perhaps the most persuasive suggestion of an Old Testament antecedent to the imagery here has been Isa. 51:1-2, a passage that is also of key hermeneutical importance in a Second Temple document like Pseudo-Philo (L.A.B. 23.4). Here, Abraham and Sarah are the rock (צור, LXX $\sigma \tau \epsilon \rho \epsilon \dot{\alpha} \nu ~ \pi \epsilon ́ \tau \rho \alpha \nu)$ from which faithful Israelites were hewn - those who await God's comforting of Zion and saving rule over the Gentiles (51.3-5). Like some other commentators, Davies and Allison profess to 'detect design' in what they regard as an antithetical parallel between the ecclesiological pioneers Abram-Abraham and Simon-Peter, both of whose names are changed, who are likened to a rock, and who bring forth a new people. Peter, on this reading, replaces Abraham. ${ }^{93}$

As an exegesis of Matt. 16:18, this is arguably not the most obvious exposition, however typologically enlightening it may seem to Christian exegetes like Davies and Allison. An initial problem is that in Isa. 51:1 (as indeed in L.A.B. 23.4) the image is of a quarry, not of a building: the metaphor of the rock therefore concerns the source rather than the foundation of a building. More seriously for Davies and Allison's interpretation, there is no hint here of a substitution of Peter for Abraham, which would in any case gravely undermine Matthew's claim that in Jesus the Law and the prophets are fulfilled rather than replaced. As Luz rightly notes, Matthew himself does not assert

\footnotetext{
90 Ilan 2002 s.v. The first of these is Petros (c. 30 CE), a freedman of Agrippa's mother Berenice, whom Josephus mentions in passing in Ant. 18.6.3 $\$ 156$ (v.l. Protos). The other two names are Patrin פטרין son of Istomachus at Masada (ostracon no. 413, pre-73) and Patron son of Joseph in a Bar Kokhba period papyrus deed at Nahal Hever (P.Yadin 46, 134 CE). Although these two names seem at first sight different from Petros, the Aramaic rendition of

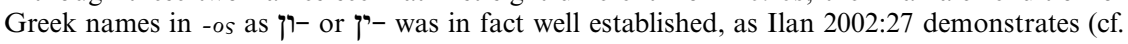
similarly Dalman 1905:176).

91 E.g. y. Mo'ed Qat. 3.6, 82d (bottom); y. 'Abod. Zar. 3.1, 42c; Gen. Rab. 62.2; 92.2; 94.5; Exod. Rab. 52.3; Lev. Rab. 7.2. For additional references and discussion see Bacher 189299:1.128, 2:512, n. 5, and 3:598. The phenomenon of the Greek name פיטרס is also discussed by Dalman 1905:185. Cf. further Jastrow s.v.: the spelling varies from פיטרס to פיטרוס and פטרס. This in turn would account for the wide range of vocalisations encountered in the various English translations. פטרוס in t. Demai 1.11 is a place-name.

92 Noy $1993-95: 1$ no. 8 (=CIJ 12:643a). Noy's conviction (p. 14) that this is a baptismal name seems plausible, but may need to be tempered by the rabbinic use of that name.

93 Davies and Allison 1988-97:2.624, 'Here the new people of God is brought into being, hewed not from the rock Abraham but instead founded on the rock Peter' (with reference to Matt. 3:9; italics mine).
} 
Peter as a sort of Isaianic new Abraham, either here or elsewhere; ${ }^{94}$ and he is not so interpreted in early Christian tradition.

There is, on the other hand, a substantial rabbinic tradition of interpretation, ignored by Davies and Allison, which may turn out after all to lend credence to a reading of Matthew 16 in terms of Abraham. While Isaiah 51:1-2 is significant for this reading, a number of Pentateuchal passages are equally influential. One of these is Numbers 23:9, where Balaam's seeing Israel 'from the top of the crags' (מראש צורים) is surprisingly widely applied to the merits of Abraham and the fathers as the rocks. ${ }^{95}$ Emphasis on Abraham as the rock also occurs repeatedly in interpretations of Deut. 32:30. ${ }^{96}$

Of particular interest here is a somewhat later rabbinic text that combines the two passages together with the Greek loan word $\pi \epsilon \tau \rho \alpha$. The thirteenthcentury 'midrashic thesaurus' ${ }^{97}$ known as Yalqut Shim 'oni, which reproduces parts of the fourth-century ${ }^{98}$ Midrash Yelamdenu and other earlier works, quotes the following mašal on Isaiah $51: 1-2$ in its comment on Numbers 23:9: 99

This can be compared to a king who desired to build a palace. He began digging, searching for solid rock on which he could lay a foundation [ $\theta \epsilon \mu \epsilon \lambda_{\iota \circ}$, תמליוס], but he found only a bog. He dug in several other sites, always with the same result. However, the king did not give up. He dug in still another location. This time he struck solid rock [ $\pi \epsilon \tau_{\tau \alpha}$, היה מוצא למטה פטרא]. 'Here I will build,' he said, and he laid a foundation [ $\theta \epsilon \mu \epsilon \lambda_{\iota \circ s}$, תמליוס] and built. In the same manner, the Holy One, blessed is he, before he created the world, sat and examined the generation of Enosh and the generation of the Flood. He said to himself, 'How can I create the world when those wicked people will appear and provoke me to anger?' When, however, the Holy One, blessed is he, looked forward to Abraham who was to come, he said, 'Here I have found solid rock [פטרא] on which I can build and upon which I can lay the world's foundations. Therefore he called Abraham 'rock' [צור], as it is written: 'Look to the rock from which you were hewn' (Isa. 51:1). But Israel he called 'rocks' [צורים] (cf. Num. 23:9). And thus he says, 'Remember your congregation, which you acquired long ago' (Ps. 74:2). ${ }^{100}$

Part of this passage has periodically surfaced in the exegetical literature on

94 So rightly Luz 1985-2002:2.462. Matt. 3:9, which Davies and Allison 1988-97:2.624 adduce as a parallel allusion to Isa. 51:1-2, seems rather far-fetched and (aside from the reference to Abraham) shows no verbal echoes of Isa. 51:1-2 - and bears no obvious relation either to Peter or to Matt. 16:18. As both Paul and James understood, though Marcion did not, it is theologically indispensable to faith in Jesus as the promised Messiah that Abraham should remain the forefather of all believers, 'old' and 'new'. The notion that Peter had replaced Abraham would, one suspects, have filled a man of Matthew's hermeneutical convictions with dismay.

95 The merits of the 'fathers' who are the 'rocks' in Num. 23:9: Tanh. Balaq 19 (114), ed. Buber 4.143 (also noted by Rashi ad loc.); Targ. Ps.-J. and Targ. Neof. Num. 23:9; Mek. Beshallah 1, ed. Horovitz/Rabin p. 179; Pesiq. R.. 12.5, etc.

96 E.g. Pesiq. Rab Kah. 5.2 par. Pesiq. Rab. 15.2 (Deut. 32:30 with Isa. 51:1); Gen. Rab. 44.21.

97 Stemberger 1996:351.

98 Stemberger 1996:300 agrees with Böhl 1977:90 that the substance of this material predates the year 400 .

99 Yalqut Num. $23.9 \$ 766$ (ed. Jerusalem 1968, p. 265d).

100 Translation partially adapted from Bivin 1994. The passage is also quoted in the Arukh (cf. Jastrow s.v. פטרא). 
Matthew since Paul Billerbeck offered a translation in his rabbinic NT commentary. ${ }^{101}$ Nowadays, however, it is almost invariably rejected as a patent case of later anti-Christian apologetic and therefore useless for any arguments about the New Testament. ${ }^{102}$

Without entering into a full discussion of the complex historical and literary critical issues, four points of critique are nevertheless worth raising against such a quick dismissal of the Yalqut passage.

1. First, it is precisely the absence of arguments from Isaiah 51 in Matthew 16 that lends all the more significance to that prophetic text's intrinsic importance for Judaism - not just in the Yalqut, but in a range of Jewish texts dating back at least as early as Pseudo-Philo, if not indeed to the Septuagint. ${ }^{103}$

2. Both Isaiah 51:1-2 and rabbinic interpretations of Num. 23:9 typically speak not just univocally of Abraham, but in the same breath of Sarah or indeed of the fathers and mothers of Israel. That too would seem to call into question the notion of any knee-jerk anti-Petrine apologetics.

3. There is in fact a robust a priori linguistic case against the commentators' undocumented assumption of Christian influence behind the loan word פטרא. Scholars like Samuel Krauss, Saul Lieberman and Daniel Sperber have long since amply documented the extent to which rabbinic texts especially of pre-Islamic Palestine abound in Greek loan words. ${ }^{104}$ Even Petros is an unabashedly rabbinic name, as we saw earlier; and the term petra for a rock is also found in Talmud Yerushalmi. ${ }^{105}$ This penchant for loan words is clearly also shared by our midrashist. His architectural parable not only uses the word $\pi \epsilon \tau \rho a$ twice, but also resorts just as happily to the complementary term $\theta \epsilon \mu \epsilon \lambda_{\iota}$ เos, which does not feature in Matthew 16 or any other Petrine texts of the New Testament. ${ }^{106}$ (It is in fact almost never applied to Peter in Christian texts of the first four centuries. ${ }^{107}$ )

101 Str-B 1.733. Among the more positive discussions is Aus 1979:258-59 (whose overall argument is more concerned with the link between the pillars of Gal. 2 and the rabbinic idea of the merit of the three fathers and four mothers of Israel) and Bivin 1994.

102 So e.g. Luz 1985-2002:2.462, n. 66, following Lampe 1979:243; similarly Davies and Allison 1988-97:2.624. Bivin 1994 is more sanguine.

103 See above; cf. similarly Pes. R. 15.2. The pleonastic LXX translation $\sigma \tau \epsilon \rho \epsilon \dot{\alpha} \nu ~ \pi \epsilon ́ \tau \rho a \nu$ may suggest a desire for emphasis (other examples include Deut. 32:13; Isa. 2:21).

104 E.g. Krauss 1898, Lieberman 1994 and Sperber 1982.

105 E.g. y. Šebi. 5.4, 36a10 (somewhat unusually spelled פוטרה; cf. also Jastrow s.v.).

106 Cf. 1QH 14(=6).26: God places the foundation (סוד) upon the rock (סלא).

107 See, however, Ep. Clement to James 1; Ps.-Clem. Hom. 17.19. Fourth-century and later works include Asterius, Hom. 8.4.2; John Chrysostom, Freq. Conv. (MPG 63.466); Canon 1.1.3 of

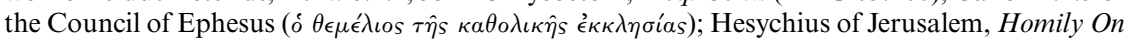
St Andrew 2.4 (ed. Aubineau 1978, pp. 240-60) speaks of Andrew as 'the firstborn of the chorus of apostles, the first-made pillar of the church, Peter before Peter, the foundation of the founda-

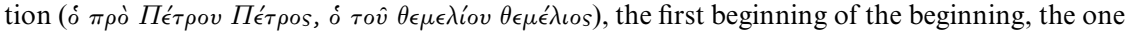
who called before being called, sealed before being sealed, and brought before being brought ...' The verb $\theta \epsilon \mu \epsilon \lambda_{\iota} o \omega$ is attested only marginally earlier (e.g. in Ps.-Ignatius, Magn. 10.2; Epiphanius, Pan. 59.7 (GCS 2.372-73). 
4. Last, but by no means least, we must note that the sort of anti-Petrine Jewish bias presupposed by Matthean commentators would in fact be a very odd business indeed. There is, as we have already seen, very little evidence that rabbinic writings are specifically concerned about Peter or indeed about Christian claims for him. But it is striking that the handful of explicit Jewish references to Peter in the later rabbinic period are in fact consistently complimentary rather than critical in their estimation of him, as can be seen most easily in the Toledot Yeshu complex of traditions and in the related attribution to Peter of a number of prominent synagogal piyyutim including Nishmat Kol Hay. A fuller discussion of the Toledot material must be left for another occasion. It seems to me possible that its picture of Peter reflects exposure to Jewish Christian views of the sort that are attested in the Pseudo-Clementines. Suffice it for now, however, to suggest that the clear preponderance of the evidence seems to make anti-Petrine polemic in Yalqut unlikely both prima facie and in view of my three earlier points. It is a premise that would at the very least need to be demonstrated rather than assumed.

If for the moment we accept that Yalqut on Numbers 23:9 is an intrinsically Jewish parable, it is clear that in rabbinic terms it would make perfect sense to describe Abraham and other fathers and mothers of Israel as a foundation of solid rock upon whom the congregation of Israel was built. (The notion of God establishing his chosen man in order to 'build' his congregation is already present in the Qumran Psalms pesher. ${ }^{108}$ )

I have not indeed adduced any direct parallel to the Petros-petra word play. But given the clear Talmudic attestation of both the name Petros and the loan word petra, it is clear that the rabbinic scope for the sort of word play represented in Matthew 16:18 is considerably greater than has often been assumed. Whether it also underlies Matthew's own source or even the Aramaic words of Jesus is a matter that would require more extensive discussion. ${ }^{109}$ But the apparent possibility of a bilingual Sitz im Leben of Petros would shed interesting light on the critical consensus that both Peter and Cephas are names that date from the very earliest period of the Jesus movement. This might in turn help to account for a number of additional oddities in the New Testament usage of Simon's Greek and Aramaic epithets - including the absence of 'Cephas' from Matthew 16:18, where the Aramaic patronym might have led us to expect it, and the abrupt change to 'Peter' in Paul's account of the Jerusalem Agreement at Galatians 2:7-8, where Cephas might have been thought more likely. From a rabbinic point of view, there is no reason to query the idea of an Aramaic-speaking Simon bar Yonah who was surnamed Petros (and later Cephas), or that an architectural word play on petra would be anything other than self-explanatory.

108 הכינו לבנות לו עדת: 4Q171 (4QpPsa) 3.16. Cf. Meier 1991-2001:3.230, who draws attention to the same passage.

109 Pace Bivin 1994, who assumes it too easily. 


\section{Conclusion}

Four simple conclusions may be stated for the benefit of future discussion. First, Simon Peter bears an Israelite patriarch's name that had returned to popularity only about 200 years earlier, apparently in connection with Jewish hopes for national restoration. This is a resonance that may still have been understood by the time of Peter's birth in the late first century BCE.

Second, rabbinic and epigraphic sources confirm Šimon bar Yonah as a sound Jewish name with a familiar and perhaps particularly Galilean patronym. There is certainly no prima facie need to presuppose either a typological reference to the biblical prophet or a coded hint at insurrectionist tendencies. From the rabbinic perspective, the Fourth Gospel's apparently straightforward connection between Yonah and John seems unlikely, although it cannot perhaps be entirely ruled out.

Thirdly, while $K \bar{e} f a$ ' makes good Aramaic sense and can be satisfactorily explained both from the Dead Sea Scrolls and from rabbinic sources, there is no evidence that it was in use in Palestine as either a Jewish or even a Christian name at any time in late antiquity. Despite Joseph Fitzmyer's best efforts to the contrary, therefore, this designation would have struck the rabbis as an intelligible but rather unusual epithet. Even in the Aramaic-speaking churches of first-century Judaea, it was this unique appellation that most clearly distinguished Peter. This realisation may in turn explain why Paul retains this nomenclature as his own preferred usage, after visiting 'the churches of Judaea that are in Christ' deliberately in order to 'make the acquaintance of Cephas' (Gal. 1:18, 22).

And finally, while Greek speakers inevitably account for the preponderance of Petros in the New Testament and subsequently, the apostle's unusual linguistic background in Bethsaida allows for the possibility that he may have been called Petros from the start. If so, it is worth pondering the possibility that it was Jesus who applied to him the Aramaic translation $K \bar{e} f a$ ' as a new nickname, interpreting his Greek name in Jewish terms and thus ensuring this new appellation's enduring importance. Either way, Palestinian Jews of the early rabbinic period would have no trouble understanding either the name Petros or a word play on the Greek word petra, which features both in the Septuagint and in midrash to identify a faithful person on whom God builds the foundation of his people. 


\section{WORKS CITED}

Allegro, John Marco. 1979. The Dead Sea Scrolls and the Christian myth. Newton Abbot: Westbridge Books.

Allison, Dale C. 1992. 'Cephas and Peter: One and the Same.' JBL 111: 489-95.

Arav, Rami and Richard A. Freund, eds. 1995-1999. Bethsaida: A City by the North Shore of the Sea of Galilee. 2 vols. Kirksville: Thomas Jefferson University Press.

Aus, Roger D. 1979. 'Three Pillars and Three Patriarchs: A Proposal Concerning Gal. 2:9.' $Z N W 70: 252-61$.

Avi Yonah, Michael. 1961. Review of B. Bagatti \& J. T. Milik, Gli scavi del 'Dominus flevit', vol. 1 (Jerusalem: Franciscan, 1958). Israel Exploration Journal 11: 91-94.

Bacher, Wilhelm. 1892-99. Die Agada der palästinensischen Amoräer. 3 vols. Strasbourg: K.J. Trübner.

Bagatti, Bellarmino. 1953. 'Scoperta di un cimitero giudeo-cristiano al "Dominus Flevit".' $L A S B F$ 3: 149-84.

Bagatti, Bellarmino and J. T. Milik. 1958. Gli scavi del 'Dominus Flevit' (Monte Oliveto-Gerusalemme). Publications of the Studium Biblicum Franciscanum 13. Jerusalem: Franciscan Printing Press.

Bauckham, Richard. 1996. 'Nicodemus and the Gurion Family.' Journal of Theological Studies ns 47: 1-37.

Bivin, David. 1994. 'Matthew 16:18 - The Petros-Petra Wordplay: Greek, Aramaic or Hebrew?' Jerusalem Perspective 46-47: 32-36, 38.

Bockmuehl, Markus. 2003. 'Simon Peter and Bethsaida.' In James the Just and Simon Peter: Uneasy Partners in the Christian Mission. Ed. B. Chilton and C. A. Evans. NTSup. Leiden: Brill.

Böhl, Felix. 1977. Aufbau und literarische Formen des aggadischen Teils im JelamdenuMidrasch. Wiesbaden: Steiner.

Brown, Colin. 1987. 'The Gates of Hell and the Church.' In Church, Word and Spirit: Historical and Theological Essays in Honor of Geoffrey W. Bromiley, 15-43. Ed. J. E. Bradley and R. A. Muller. Grand Rapids: Eerdmans.

Charlesworth, James H. 1985. The Discovery of a Dead Sea Scroll (4Q Therapeia): Its Importance in the History of Medicine and Jesus Research. ICASALS Publication 85-1. Lubbock: Texas Tech University.

—. 1987. 'A Misunderstood Recently-Published Dead Sea Scroll (4QM 130).' Explorations: The American Interfaith Newsletter 1, no. 1: 2.

_ 1992. 'Has the name "Peter" been found among the Dead Sea Scrolls?' In Christen und Christliches in Qumran?, 213-225. Ed. B. Mayer. Eichstätter Studien N.S. 32. Regensburg: Verlag Friedrich Pustet.

Chilton, Bruce. 2000. Rabbi Jesus: An Intimate Biography. New York: Doubleday.

—. 2001. 'Friends and Enemies.' In The Cambridge Companion to Jesus, 72-86. Ed. M. Bockmuehl. Cambridge: Cambridge University Press.

Colpe, Carsten. 1975. 'Bostra.' KlPauly 1: 935.

Conzelmann, Hans. 1965. 'Zur Analyse der Bekenntnisformel 1 Kor 15,3-5.' EvT 25: $1-11$.

Cullmann, Oscar. 1956. 'Petros, Kéfas.' TWNT 6: 99-112.

—. 1962. Peter: Disciple, Apostle, Martyr. A Historical and Theological Study. Trans. F. V. Filson. 2nd edn. London: SCM.

- 1963. The State in the New Testament. Rev. edn. London: SCM. 
1970. Jesus and the Revolutionaries. New York: Harper \& Row.

Dalman, Gustav. 1905. Grammatik des jüdisch-palästinischen Aramäisch nach den Idiomen des palästinischen Talmud, des Onkelostargum und Prophetentargum, und der jerusalemischen Targume. 2nd edn. Leipzig: Hinrichs.

Davies, W. D. and Dale C. Allison. 1988-97. A Critical and Exegetical Commentary on the Gospel According to Saint Matthew. ICC. 3 vols. Edinburgh: T. \& T. Clark.

Diebner, Bernd Jörg. 1998. “"Glückselig bist du, Simon, Sohn des Jona” (Mt 16,17): Anmerkungen zum "Vaternamen" des Apostel-Fürsten.' DBAT 29: 207-16.

Dinkler, Erich. 1961. 'Petrus, Apostel.' In $R G G, 5,247-49$. 3rd.

Ehrman, Bart D. 1990. 'Cephas and Peter.' JBL 109: 463-74.

Eisler, Robert. 1929. Iesous basileus ou basileusas: Die messianische Unabhängigkeitsbewegung vom Auftreten Johannes des Täufers bis zum Untergang Jakobs des Gerechten. Religionswissenschaftliche Bibliothek 9.1-2. Heidelberg: C. Winter.

Erbes, Carl. 1901. 'Petrus nicht in Rom, sondern in Jerusalem gestorben.' ZKG 22: $1-47,161-231$.

Finegan, Jack. 1992. The Archeology of the New Testament: The Life of Jesus and the Beginning of the Early Church. Rev. edn. Princeton: Princeton University Press.

Fitzmyer, Joseph A. 1971. 'The Name Simon.' In Essays on the Semitic Background of the New Testament, 105-12. London: Chapman.

_ 1998. 'Aramaic Kepha' and Peter's Name in the New Testament.' In To Advance the Gospel: New Testament Studies, 112-24. The Biblical Resource Series. 2nd edn. Grand Rapids/Cambridge: Eerdmans.

Fitzmyer, Joseph A. and Daniel J. Harrington. 1978. A manual of Palestinian Aramaic texts: (second century B.C.-second century A.D.). Biblica et orientalia 34. Rome: Biblical Institute Press.

Gilman, Jean. 1998. Jerusalem Burial Cave Reveals: Names, Testimonies of First Christians. Vol. 9:2. Jerusalem Christian Review. Accessed 14.2.2003. Available from www.christian.edu.

Ginzberg, Louis. 1967. The Legends of the Jews. 6 vols. Philadelphia: Jewish Publication Society of America.

Greenhut, Zvi. 1992. 'Burial cave of the Caiaphas family: [map, plans, photos].' Biblical Archaeology Review 18: 28-36,76.

Gundry, Robert Horton. 1994. Matthew: A Commentary on his Handbook for a Mixed Church under Persecution. 2nd edn. Grand Rapids: Eerdmans.

Hagner, Donald A. 1993-95. Matthew. WBC 33A-B. 2 vols. Dallas: Word.

Hengel, Martin. 1989. The Zealots: Investigations into the Jewish Freedom Movement in the Period from Herod I until 70 A.D. Trans. D. Smith. Edinburgh: T. \& T. Clark.

Hirschberg, H. 1942. 'Simon Bariona and the Ebionites.' JBL 61: 171-91.

Horbury, William. 1994. 'The "Caiaphas" Ossuaries and Joseph Caiaphas: [bibliog, map].' Palestine Exploration Quarterly 126: 32-48.

Hübner, Ulrich. 1992. 'Bozrah.' ABD 1: 774-76.

Ilan, Tal. 2002. Lexicon of Jewish Names in Late Antiquity, Part I: Palestine 300 BCE200 CE. TSAJ 91. Tübingen: Mohr Siebeck.

Isbell, Charles D. 1975. Corpus of the Aramaic Incantation Bowls. Missoula: Scholars Press.

Jeremias, Joachim. 1938. 'Ionas.' TWNT 3: 410-13. 
1969. Jerusalem in the Time of Jesus: An Investigation into Economic and Social Conditions During the New Testament Period. Trans. F. H. Cave and C. H. Cave. Philadelphia: Fortress Press.

Klijn, A. F. J. 1992. Jewish-Christian Gospel Tradition. Supplements to VC 17. Leiden/New York: Brill.

Kneller, Carl A. 1902. 'S. Petrus Bischof von Rom.' ZKT 26: 33-69.

Krauss, Samuel. 1898. Griechische und lateinische Lehnwörter im Talmud, Midrasch und Targum. 2 vols in 1. Berlin: S. Calvary.

—. 1902. Das Leben Jesu nach jüdischen Quellen. Berlin: S. Calvary.

Lake, K. 1921. 'Simon, Cephas, Peter.' HTR 14: 95-97.

Lampe, Peter. 1979. 'Das Spiel mit dem Petrus-Namen, Matt. 16:18.' NTS 25: 227-45.

Lieberman, Saul. 1994. Greek in Jewish Palestine; Hellenism in Jewish Palestine. 2nd edn. New York: Jewish Theological Seminary of America.

Luz, Ulrich. 1985-2002. Das Evangelium nach Matthäus. EKKNT 1.1-4. 4 vols. Zurich/Neukirchen-Vluyn: Benziger/Neukirchener.

Maier, Johann. 1978. Jesus von Nazareth in der talmudischen Überlieferung. Erträge der Forschung 82. Darmstadt: Wissenschaftliche Buchgesellschaft.

Marcus, R. 1942. 'A Note on Bariona.' JBL 61: 281.

Meier, John P. 1991-2001. A Marginal Jew: Rethinking the Historical Jesus. ABRL. Vol. 1-3. New York: Doubleday.

Naveh, Joseph. 1986. 'A Medical Document or a Writing Exercise: The So-Called 4Q Therapeia.' Israel Exploration Journal 36: 52-55.

—. 2000. '341: 4QExercitium Calami C.' DJD 36: 291-93, pl. XVIII.

Niese, Benedikt. 1885. Flavii Iosephi Opera. 7 vols. Berlin: Weidmann.

Noy, David. 1993-95. Jewish Inscriptions of Western Europe. Vol. 2 vols. Cambridge: Cambridge University Press.

Petersen, William L. 1992. 'Zion Gospel Edition.' ABD 6: 1097-98.

Peterson, F. Paul. 1960. Peter's Tomb Recently Discovered in Jerusalem. Fort Wayne: privately published.

Rahmani, L. Y. 1994. A Catalogue of Jewish Ossuaries in the Collections of the State of Israel. Jerusalem: Israel Antiquities Authority/Israel Academy of Sciences and Humanities.

Reich, Ronny. 1992. 'Caiaphas' name inscribed on bone boxes: [in Jerusalem cave tomb; facsims, photos].' BAR 18: 38-44,76.

Riesner, Rainer. 1994. 'James's Speech (Acts 15:13-21), Simeon's Hymn (Luke 2:29_ 32), and Luke's Sources.' In Jesus of Nazareth, Lord and Christ: Essays on the Historical Jesus and New Testament Christology, 263-78. Ed. J. B. Green and M. Turner. Grand Rapids: Eerdmans.

Robinson, Bernard P. 1984. 'Peter and his Successors: tradition and redaction in Matthew 16,17-19.' JSNT 21: 85-104.

Schürer, Emil. 1973-86. A History of the Jewish People in the Age of Jesus Christ. Ed. G. V. e. al. 3. Rev. edn. Edinburgh: T. \& T. Clark.

Schlatter, Adolf. 1930. Der Evangelist Johannes. Stuttgart: Calwer.

Schwabe, Moshe and Baruch Lifshitz. 1973. The Greek Inscriptions. Ed. B. Mazar. Beth She'arim: Report on the Excavations during 1936-1940, vol. 2. Jerusalem: Massada Press. 
Schwartz, Joshua. 1995. 'Ben Stada and Peter in Lydda.' In The Book of Acts in its Palestinian Setting, 391-414. Ed. R. Bauckham. The Book of Acts in its First Century Setting 4. Grand Rapids/Carlisle: Eerdmans/Paternoster. Original edition, JSJ 21 (1990) 1-18.

Smith, Robert Houston. 1974. 'Cross marks on Jewish ossuaries.' Palestine Exploration Quarterly 106: 53-66.

Sperber, Daniel. 1982. Essays on Greek and Latin in the Mishna, Talmud and Midrashic literature. Jerusalem: Mekor.

Stemberger, Günter. 1996. Introduction to the Talmud and Midrash. Ed. M. Bockmuehl. 2nd edn. Edinburgh: T. \& T. Clark.

Taylor, Joan E. 1993. Christians and the Holy Places: The Myth of Jewish-Christian Origins. Oxford/New York: Oxford University Press.

Theissen, Gerd. 1978. Sociology of Early Palestinian Christianity. Trans. J. Bowden. Philadelphia: Fortress.

Thiede, Carsten Peter. 2000. Geheimakte Petrus: Auf den Spuren des Apostels. Stuttgart: Kreuz Verlag.

van der Ploeg, J. 1960. Review of B. Bagatti and J.T. Milik, Gli scavi del 'Dominus flevit', vol. 1 (Jerusalem: Franciscan, 1958). JSS 5: 81-82.

Wall, Robert W. 1987. 'Peter, "Son of Jonah": The Conversion of Cornelius in the Context of Canon.' JSNT 29: 79-90. 